\title{
EVALUATION OF QUALITY OF LIFE IN PATIENTS TREATED FOR METASTATIC DISEASE OF THE PROXIMAL FEMUR
}

\author{
AVALIAÇÃO DA QUALIDADE DE VIDA EM PACIENTES TRATADOS \\ POR DOENÇA METASTÁTICA DA REGIÃO PROXIMAL DO FÊMUR
}

\author{
Marcos Hajime Tanaka ${ }^{1}$, Marcello Martins de Souza ${ }^{1}$, Daniel Luiz Ceroni Gibson ${ }^{1}$, Monica Paschoal Nogueira ${ }^{1}$ \\ 1. Hospital do Servidor Público Estadual, São Paulo, Brazil.
}

\begin{abstract}
Objective: Patients with metastatic bone lesions have a limited life expectancy. These metastatic lesions compromise the proximal femur, and fractures are quite common. The survival of these patients depends on the behavior of the primary tumor. The aim of this study was to evaluate the quality of life of patients with extensive metastatic lesion of the proximal femur with pathological or imminent fracture, treated with non-conventional endoprosthesis. Methods: From May 2008 to August 2012, twenty-five (25) patients with bone metastases of the proximal femur, with pathological or imminent fracture were recruited into this study. These patients had survived for at least six weeks after surgery and the TESS questionnaire (Toronto Extremity Salvage Score) was administered. Results: The final score of the TESS was an average of 57 points (SD 23.78 points). There was no significant difference in TESS values considering: sex, presence of fracture, or site of the bone lesion. Conclusion: The TESS questionnaire provides information about the function and quality of life of patients with malignant tumors of the lower limbs, from the patient's perspective. The results can be considered positive, when compared to the limited life expectancy and complexity of this group of patients. Level of evidence III, Therapeutic studies, retrospective comparative study.
\end{abstract}

Keywords: Femoral Neoplasms/surgery. Prostheses and Implants. Quality of Life. Surveys and Questionnaires. Neoplasm Metastasis.

\section{RESUMO}

Objetivo: Pacientes com lesões ósseas metastáticas têm expectativa de vida limitada. Essas lesões metastáticas comprometem a parte proximal do fêmur, e as fraturas são bastante comuns. A sobrevida desses pacientes depende do comportamento do tumor primário. O objetivo deste estudo é avaliar a qualidade de vida de pacientes com lesões metastáticas extensas na parte proximal do fêmur com fratura patológica ou iminente, tratados com endopróteses não convencionais. Métodos: De maio de 2008 a agosto de 2012, vinte e cinco (25) pacientes com metástases ósseas da parte proximal do fêmur com fratura patológica ou iminente foram recrutados para este estudo. Esses pacientes tinham sobrevida de pelo menos seis semanas após a cirurgia e o questionário TESS (Toronto Extremity Salvage Score) foi aplicado. Resultados: O escore final do TESS teve média de 57 pontos (DP de 23,78 pontos). Não houve diferença significativa entre os valores do TESS ao se considerar sexo, presença de fratura ou localização da lesão óssea. Conclusão: O questionário TESS fornece informações sobre a função e a qualidade de vida dos pacientes com tumores malignos dos membros inferiores, do ponto de vista do paciente. Os resultados obtidos podem ser considerados positivos, diante da expectativa de vida limitada e a complexidade desse grupo de pacientes. Nível de evidência III, Estudos terapêuticos, Estudo retrospectivo comparativo.

Descritores: Neoplasias femorais/cirurgia. Próteses e implantes. Qualidade de vida. Inquéritos e questionários. Metástase neoplásica.

Citation: Tanaka MH, Souza MM, Gibson DLC, Nogueira MP. Evaluation of quality of life in patients treated for metastatic disease of the proximal femur. Acta Ortop Bras. [online]. 2018;26(4):248-51. Available from URL: http://www.scielo.br/aob.

\section{INTRODUCTION}

The incidence of bone metastatic disease is on the increase as cancer patients now live longer. ${ }^{1}$ The most common site of metastases is the bone, followed by the lungs and liver. ${ }^{2,3}$ Breast and prostate cancers are the two largest sources of bone metastasis (80\%). ${ }^{4}$. In cancer patients, bone metastasis is a common cause of decreased quality of life. ${ }^{5}$ One third of skeletal lesions occur in the proximal femur. ${ }^{6}$ Approximately $10 \%$ of patients suffering from metastatic disease have pathological fractures and $65 \%$ of these fractures (requiring surgical treatment) occur in the femur. ${ }^{7}$ Pathological fractures or imminent proximal femur fractures can have a disastrous effect on quality of life, resulting in pain and incapacitation, with great impact on the lives of these patients. In recent years, the survival time after diagnosing bone metastasis has increased with advances in oncology, especially in patients with breast and prostate cancers. Surgical considerations include tumor location, type and size of the lesion and conditions inherent to the clinical and emotional state of the patient.

All authors declare no potential conflict of interest related to this article. 
Most metastatic bone lesions are effectively treated by non-surgical methods such as radiotherapy, chemotherapy, immunotherapy, hormone therapy and administration of bisphosphonates. ${ }^{8,9}$

In the presence of pathological or imminent fracture of the proximal femur, surgical treatment is usually the best option. Bone infiltration by metastatic cancer causes weakness and requires prostheses or implants, to last the remaining life of the patients. ${ }^{10}$ Reconstruction with endoprosthesis is indicated in patients with major bone destruction. It has low rates of complications and failures and besides that provides relief of pain and restoration of limb function. The most commonly used functional evaluations for patients with bone cancer are: the Musculoskeletal Tumor Society Rating Scale $(\text { MSTS })^{11,12}$ the Toronto Extremity Salvage Score (TESS) ${ }^{13}$ and Short Form 36 (SF-36) ${ }^{14}$ Each of these evaluations covers a different definition of the functional aspect. The TESS is a self-administered questionnaire which is easy to understand and can be sent to the patient by mail. Also, it is one of the questionnaires most commonly used in studies involving functional evaluation in patients with malignant bone tumors and soft tissue sarcomas of the extremities. ${ }^{15}$ The TESS (Toronto Extremity Salvage Score) ${ }^{13}$ was the chosen instrument used in this study. Information was obtained about the impression and perception of patients who had undergone treatment; the function and quality of life were also evaluated without interference from the doctor.

\section{MATERIALS AND METHODS}

After obtaining approval from the ethics committee under CAAE number: 01390.0388.000-10,36 consecutive patients who underwent surgical treatment with endoprosthesis between May 2008 and August 2012 were selected retrospectively (with bone metastases or multiple myeloma of the proximal femur with pathological or imminent fracture)

All the patients completed and signed the questionnaire under the researcher's supervision, and those who could not or experienced difficulties coming to the hospital answered the questionnaire and sent them by mailing. From the total of 36 patients, only 25 participated in the study. Five had died at the time of this study, four were not found and two refused to participate. The surgical indication of endoprosthesis of the proximal femur was indicated in treating lesions with extensive destruction.

The Mirels index score evaluates the risk of pathologic fracture of long bones. This index is based on the anatomical location, pain intensity, radiographic features of the lesion and percentage of bone affected. Based on their criteria, above nine points, there is an indication of surgery, even in the absence of fracture. ${ }^{16}$ In this study, Mirels criteria were used to indicate surgery in patients without fracture.

The patients answered the questionnaire after surgery (minimum 6 weeks), as well as in restrictions of body movements, mobility, self-care and performance on tasks and daily routines.

The following five questions emphasize the patient's current situation regarding occupation (employed or unemployed, student, etc), brief description of leisure and recreation activities, use of pain medications and their frequency of use, help to move or walk (stroller, crutch, sticks or wheelchair) and what factors can limit the activities of daily life (pain, stiffness, fatigue, weakness, decreased movement).

With the data collected after completing the questionnaire, analysis of the scores obtained by functional assessment (TESS) was conducted. Each question has an alternative that makes it possible to achieve between 0 to 5 points, totaling 150 points. Data collected were analyzed, and items whose answer was "this item does not apply to me", were excluded and divided by a possible score multiplied by $100 \%$. Hence, the higher scores mean better function.
A comparison of TESS scores between qualitative variables was performed using the Student t-test. Correlations between TESS scores, age and postoperative time were assessed by Pearson correlation analysis. With the evaluation of variables that together influence the TESS score, multiple regression analysis was performed.

Data analysis was performed with the statistical package SPSS 12.0 (Statistical Package for Social Sciences), (Chicago, EUA).

\section{RESULTS}

Between May 2008 to August 2012, twenty-five (25) patients answered the questionnaire. Breast tumor (48\%) was the primary tumor with the highest incidence, followed by Myeloma (24\%) and kidney tumor (12\%) (Figure 1).

The 25 patients had an average age of 60.8 years (SD 9.82), as shown in Tables 1 and 2. Six patients showed no imminent fracture and the Mirels score was 10 for 3 patients and 11 for the remaining 3 patients. In total, there were sixteen female patients (64\%) and 9 male patients (36\%) (Table 1 ).

From the total of 25 patients, only 17 (68\%) had fracture/injury in the femoral neck while $8(32 \%)$, had it in the peritrochanteric region. Nineteen (19) patients (76\%) presented with a pathologic fracture (Table 2).

The questionnaire was applied between 2 months to 3 years postoperatively (11.96 \pm 10.64$)$. Function was measured by TESS score ranging from 7.5 to 91.7 (57.83 \pm 23.78$)$. By assessing different patient characteristics and associating them with the TESS score, there was no statistically significant difference between the groups in relation to any qualitative variable (Table 2).

The correlation between quantitative variables is low. Although they were weak and negative, with increasing age there was a tendency for smaller TESS value, and more time after surgery, reduced the TESS (Table 3). Multiple regression analysis was performed to evaluate the presence of interference from the joint variables with respect to the TESS. The final model was well adjusted $(p<0.001)$ and $R^{2}=0.868$; however, only the variable gender entered the final model. The other variables were not significant for the model.

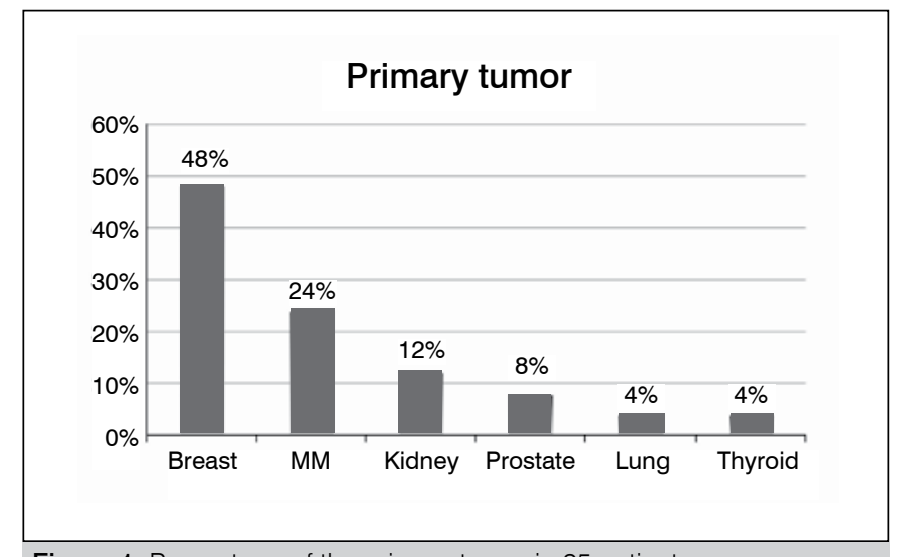

Figure 1. Percentage of the primary tumor in 25 patients.

\section{DISCUSSION}

Pathological fractures occur frequently in the proximal femur. Surgical treatment should be performed as soon as possible, because these fractures present morbidity and high risk to life. ${ }^{15,17}$ In their study, they evaluated patients with extensive lesions of the proximal femur (neck and peritrochanteric region) fracture or imminent risk of fracture, where the indication of treatment was the resection of the affected bone and its replacement by unconventional 
Table 1. Data of patients and TESS results.

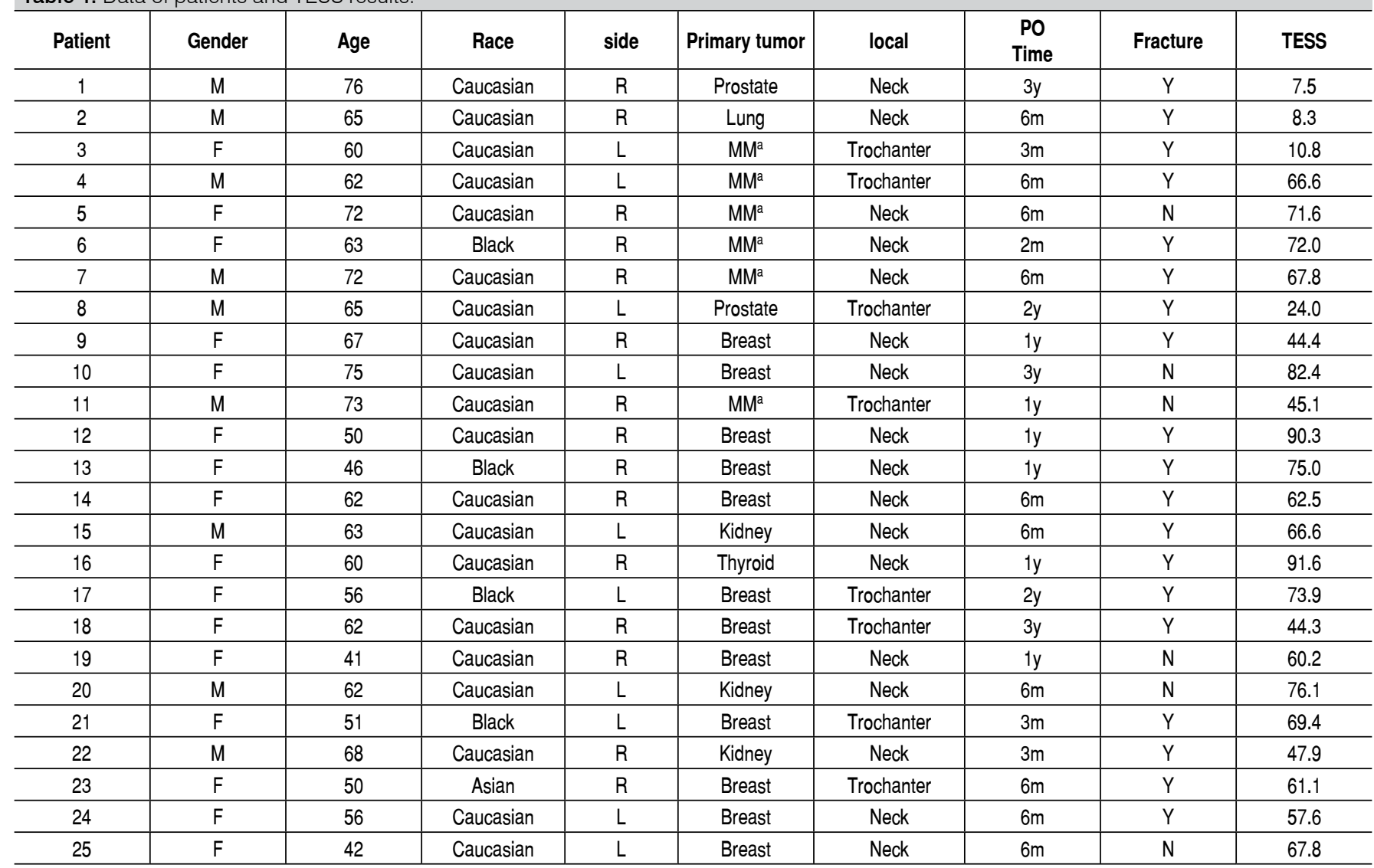

aMM: Multiple Myeloma

Table 2. Qualitative variables correlated with the TESS.

TESS

\begin{tabular}{|c|c|c|c|c|c|c|c|c|c|c|}
\hline & & $\mathrm{N}$ & Average & SD & Min & Max & Q25 & Median & Q75 & $P$ value \\
\hline \multirow{2}{*}{ Gender } & Male & 9 & 45.59 & 26.52 & 7.5 & 76.14 & 24.07 & 47.92 & 66.67 & \multirow{2}{*}{0.051} \\
\hline & Female & 16 & 64.72 & 19.73 & 10.83 & 91.67 & 58.96 & 68.65 & 74.47 & \\
\hline \multirow{2}{*}{$\begin{array}{c}\text { Age } \\
\text { group }\end{array}$} & $\leq 60$ & 10 & 65.81 & 22.56 & 10.83 & 91.67 & 60.23 & 68.65 & 75.00 & \multirow{2}{*}{0.176} \\
\hline & $>60$ & 15 & 52.51 & 23.80 & 7.5 & 82.41 & 44.32 & 62.50 & 71.67 & \\
\hline \multirow{2}{*}{ Side } & Right & 15 & 56.67 & 24.80 & 7.5 & 91.67 & 44.44 & 61.11 & 72.00 & \multirow{2}{*}{0.773} \\
\hline & Left & 10 & 59.57 & 23.35 & 10.83 & 82.41 & 57.69 & 67.27 & 73.91 & \\
\hline \multirow{2}{*}{$\begin{array}{c}\text { Place of } \\
\text { injury }\end{array}$} & Neck & 17 & 61.78 & 23.89 & 7.5 & 91.67 & 57.69 & 67.86 & 75.00 & \multirow{2}{*}{0.234} \\
\hline & Trochanter & 8 & 49.44 & 22.71 & 10.83 & 73.91 & 34.20 & 53.15 & 68.06 & \\
\hline \multirow{2}{*}{ Fracture } & No & 6 & 67.25 & 13.15 & 45.19 & 82.41 & 60.23 & 69.77 & 76.14 & \multirow{2}{*}{0.275} \\
\hline & Yes & 19 & 54.86 & 25.83 & 7.5 & 91.67 & 44.32 & 62.50 & 72.00 & \\
\hline
\end{tabular}

Table 3. Regression coefficient correlation. Variables X TESS.

\begin{tabular}{c|c|c|c}
\hline & Age & PO (months) & TESS \\
\hline Age & 1 & 0.30 & -0.32 \\
\hline PO (Months) & 0.30 & 1 & -0.17 \\
\hline TESS & -0.32 & -0.17 & 1 \\
\hline
\end{tabular}

endoprosthesis with a stem cementation in the distal femur without replacement of the acetabulum ${ }^{18}$.

The advantage of endoprosthesis is that it can efficiently stabilize the affected segment, with the improvement of pain and possibility of early ambulation. However, it is a procedure with greater likelihood of bleeding and other complications; it is considered a method with low morbidity. ${ }^{19}$

Normally, if there are no clinical complications, the patients start gait training by supporting the operated limb by weight bearing and with the aid of crutches or walker, about the second or third day after surgery. Hospital discharge usually occurs between the fifth and seventh day after surgery. It continues with home rehabilitation and after the removal of stitches the patient is referred to an oncologist, in order to continue treatment of the primary tumor and physical therapy.

Patient survival rate depends on the primary tumor. The average survival time of a patient undergoing surgical treatment for bone metastases is approximately 8.6 months. ${ }^{5}$ However, patients with more aggressive tumors as in the case of lung cancer, or other clinical problems that deteriorate the clinical condition, may have a shorter survival. Indeed the minimum period for interviewing a patient in this study was six weeks. Some patients had already died before invitations were sent. The average TESS score in this study was 57.83 .

Clayer et al. ${ }^{13}$ found statistically significant differences in the TESS values between the different age groups, with the lowest scores being in the elderly. This study, however, examined the appearance of clinical and non-surgical patients. Tunn et al. ${ }^{18}$ also demonstrated lower scores in older patients, who underwent surgery with stents. Age seems to be one of the factors that aggravate and worsen the 
quality of life of patients with bone metastasis of the proximal femur. The worst TESS score (7.5) was obtained from the older patient (76 years) with a history of prostate cancer and longer survival at the time of the interview (3 years). The highest TESS score (91.67) occurred in a 60 years old patient with thyroid cancer, with 1-year survival at the time of the interview. However, in this study TESS had no correlation with age TESS. When surgery was indicated, the final decision was taken in conjunction with the oncologist and especially with the family, leaving them to make the final decision about the surgical treatment. Cases with poor prognosis and life-threatening surgery, underwent clinical treatment with palliative clinical pain care. TESS scores reflect the patient's opinion about the activities of their daily life, which differs from the performance evaluation regarding the clinical criteria and function of the operated member from the medical professional's point of view. TESS is one of the most widely used questionnaires worldwide, in studies involving the functional assessment of patients with bone and soft tissue tumors of the extremities. There are few study treatments with endoprosthesis and TESS. The results obtained in studies involving endoprosthesis femur and TESS, show the best results in patients with primary tumors.
The results were compared with other studies by Asford et al..${ }^{19}$ and Chandrasekar et al. ${ }^{20}$, who also found TESS scores with values of 68.4 and 64 , very similar to that found in the present study (TESS $=57.85)$, with a larger number of patients in the proximal femur. On the other hand, Tunn et $a{ }^{18}{ }^{18}(2008)$ found the same value of TESS, but in another localization (distal femur, proximal femur and proximal tibia) while considering primary tumors.

\section{CONCLUSION}

Studying the results of surgical treatment for bone metastasis is difficult because bone cancer is often an advanced sign of the disease and poor prognosis. Also, metastatic tumors are all different in terms of life span, response to treatment and risk of fractures. Advanced cancer is a condition that can bring multiple complications and deterioration in general health conditions. Information about the quality of life of patients under this point of view, in the final phase of their lives, should not be neglected. In the specific case of metastatic lesions with extensive lesions of the proximal femur, TESS was able to indicate that surgery with unconventional endoprosthesis can be considered a good alternative.

AUTHORS' CONTRIBUTIONS: Each author made significant individual contributions to this manuscript. MHT (0000-0001-7824-584X)*: concept and design of the study, acquisition, analysis and interpretation of the data for the work and writing the article; MMS (0000-0003-2131-3404)*: acquisition, analysis and interpretation of the data for the work and writing the article; DLCG (0000-0001-9053-090X)*: acquisition, analysis and interpretation of the data for the work and writing the article; MPN (0000-0001-5892-2532*: Critical review of the content of the work, final approval of the version of the manuscript to be published. *ORCID (Open Researcher and Contributor ID).

\section{REFERENCES}

1. Weber KL, Lewis VO, Randall RL, Lee AK, Springfield D. An approach to the management of the patient with metastatic bone disease. Instr Course Lect. 2004;53:663-76.

2. Dorfman HD. Metastatic tumors in bone. In: Dorfman HD, Czerniak B (eds) Bone Tumors. St Louis: Mosby; 1998. p.1009-40.

3. Manoso MW, Healey JH. Metastatic cancer to the bone. IN : DeVita Jr. VT, Hellman S, Rosenberg SA (eds) Cancer: principes and practice of oncology, 7ed> Philadelphia: Lippincott Williams and Wilkins; 2005.p.2368-80

4. Bickels J, Dadia S, Lidar Z. Surgical management of metastatic bone disease J Bone Joint Surg Am. 2009;91(6):1503-16.

5. Hage WD, Aboulafia AJ, Aboulafia DM. Incidence, location, and diagnostic evaluation of metastatic bone disease. Orthop Clin North Am. 2000;31(4):515-28.

6. Harrington KD. New trends in the management of lower extremity metastases. Clin Orthop Relat Res. 1982;(169):53-61.

7. Houston SJ, Rubens RD. The systemic treatment of bone metastases. Clin Orthop Relat Res. 1995;(312):95-104.

8. Janjan NA. Radiation for bone metastases: conventional techniques and the role of systemic radiopharmaceuticals. Cancer. 1997;80(8 Suppl):1628-45.

9. Thurman SA, Ramakrishna NR, DeWeese TL. Radiation therapy for the treatment of locally advanced and metastatic prostate cancer. Hematol Oncol Clin North Am. 2001;15(3):423-43

10. Weber KL, Randall RL, Grossman S, Parvizi J. Management of lower-extremity bone metastasis. J Bone Joint Surg Am. 2006;88:11-9.

11. Enneking WF, Dunham W, Gebhardt MC, Malawar M, Pritchard DJ. A system for the functional evaluation of reconstructive procedures after surgical treatment of tumors of the musculoskeletal system. Clin Orthop Relat Res. 1993;(286):241-6.

12. Davis AM, Wright JG, Williams JI, Bombardier C, Griffin A, Bell RS. Development of a measure of physical function for patients with bone and soft tissue sarcoma. Qual Life Res. 1996;5(5):508-16.

13. Clayer M, Doyle S, Sangha N, Grimer R. The Toronto Extremity Salvage Score in unoperated controls: an age, gender, and country comparison. Sarcoma. 2012:717213.

14. Brazier JE, Harper R, Jones NM, O'Cathain A, Thomas KJ, Usherwood T, et al. Validating the SF-36 health survey questionnaire: new outcome measure for primary care. BMJ. 1992;305:160-4.

15. Ward WG, Holsenbeck S, Dorey FJ, Spang J, Howe D. Metastatic disease of the femur: surgical treatment. Clin Orthop Relat Res. 2003;(415 Suppl):S230-44.

16. Mirels $\mathrm{H}$. Metastatic disease in long bones. A proposed scoring system for diagnosing impending pathologic fractures. Clin Orthop Relat Res. 1989;(249):256-64.

17. Camargo OP, Baptista AM. Conduta atual nas lesões ósseas metastáticas. Rev Bras Ortop. 2004;39(6):273-82.

18. Tunn PU, Pomraenke D, Goerling U, Hohenberger P. Functional outcome after endoprosthetic limb-salvage therapy of primary bone tumours--a comparative analysis using the MSTS score, the TESS and the RNL index. Int Orthop.2008;32(5):619-25

19. Ashford RU, Hanna SA, Park DH, Pollock RC, Skinner JA, Briggs TW, et al. Proximal femoral replacements for metastatic bone disease: financial implications for sarcoma units. Int Orthop. 2010;34(5):709-13.

20. Chandrasekar CR, Grimer RJ, Carter SR, Tillman RM, Abudu A, Buckley L. Modular endoprosthetic replacement for tumours of the proximal femur. J Bone Joint Surg Br. 2009;91(1):108-12. 